\section{ANALISIS KRIMINOLOGI KEJAHATAN PENGGELAPAN DAN PENIPUAN DANA UMROH OLEH BIRO PENYELENGGARA PERJALANAN IBADAH UMROH PT.NABILA TRAVEL DI KOTA MEDAN}

\section{Oleh: \\ Enjang}

\section{Abstract}

The rise of fraudulent umrah funds by companies that organize Umrah trips is inseparable from the role of the government as the party that gives business permits and is the party responsible for supervising the conduct of business activities carried out by the Bureau of Organizing Umrah Worship Travels.

Based on the results of the study, it was found that the regulation of fraud and embezzlement of prospective Umrah pilgrims in Indonesian legislation, there are at least three relevant laws, namely Law No. 1 of 1956 concerning the Criminal Code, Law No. 8 of 1999 concerning Consumer Protection and Law No. 13 of 2008 concerning the Implementation of Haij and Umrah services. The cause of the fraud and fraud of Umrah funds by PT. Nabila Putra Mandiri is an encouragement in the suspect to fulfill unlimited desires (lusts) and a culture of people who are trustworthy and tempted by lure that is profitable. The government policy prevented the embezzlement of pilgrimage pilgrimage funds by the umroh travel organizer bureau, namely by making a new policy in the system of Haij and Umrah administration through the Integrated Umrah Supervision Information System and Special Hajj which was based on electronics.

Keywords: Criminology embezzlement, Fund Umrah.

\section{Abstrak}

Maraknya penipuan dana umroh oleh perusahaan penyelenggara perjalanan umroh tidak terlepas dari peran pemerintah sebagai pihak yang memberi izin usaha dan sebagai pihak yang bertanggungjawab untuk melakukan pengawasan terhadap pelaksanaan kegiatan usaha yang dilakukan Biro Penyelenggara Perjalanan Ibadah Umroh.

Pengaturan penipuan dan penggelapan dana calon jamaah umroh dalam perundangundangan di Indonesia, paling tidak terdapat tiga undang-undang yang relevan, yaitu Undang-Undang No. 1 Tahun 1956 tentang KUHP, Undang-Undang No. 8 tahun 1999 Tentang Perlindungan Konsumen dan UndangUndang No. 13 Tahun 2008 Tentang Penyelenggaraan Ibadah haji dan Umroh. Penyebab terjadinya penggelapan dan penipuan dana umroh oleh PT. Nabila Putra Mandiri adalah dorongan dalam diri tersangka untuk memenuhi hasrat (hawa nafsu) yang tidak terbatas dan budaya masyarakat yang mudah percaya dan tergiur dengan iming-iming yang menguntungkan. Kebijakan pemerintah mencegah terjadinya penggelapan dana calon jamaah umroh oleh biro penyelenggara perjalanan umroh, yaitu dengan membuat kebijakan baru dalam sistem penyelenggaraan haji dan umroh melalui Sistem Informasi Pengawasan Terpadu Umroh dan Haji Khusus yang dibangun berbasis elektronik.

Kata Kunci: Kriminologi, Penggelapan, Dana Umroh.

\section{Pendahuluan}

\section{A. Latar Belakang}

Bagi umat Islam ibadah haji adalah suatu kewajiban bagi mereka yang telah mampu baik dari segi finansial maupun fisik. Ibadah ini merupakan pelaksanaan dari rukun Islam yang kelima. Seseorang dinyatakan telah menyempurnakan keislamannya bila telah mampu melaksanakan ibadah haji. Ibadah haji 
wajib dikerjakan dengan segera, jika seseorang sudah mampu secara fisik maupun finansial maka ia harus segera mendaftarkan diri untuk mengikuti ibadah haji. ${ }^{1}$

Tingginya animo umat Islam untuk menunaikan ibadah haji menyebabkan proses pemberangkan calon jemaah haji harus menunggu lama sesuai dengan daftar tunggu yang ditetapkan oleh Departemen agama. Hal ini dikarenakan terbatasnya quota jamaah haji yang ditetapkan oleh pemerintah Arab Saudi. Akibatnya, kebanyakan orang Indonesia saat ini memilih untuk melaksanakan ibadah umroh sembari menunggu waktu keberangkatan ibadah haji tiba. Hal ini dikarenakan daftar masa tunggu calon jamah haji di Indonesia sangatlah lama berkisar 8 (delapan) sampai dengan 12 (dua belas) tahun.

Pelaksanaan ibadah umroh berbeda dengan penyelenggaraan ibadah haji. Pelaksanaan ibadah umroh tidak ada pembatasan quota, sehingga calon jamaah umroh dapat menunaikan ibadah umroh kapan saja sesuai dengan waktu yang diinginkan. Lamanya daftar tunggu pemberangkatan calon jamah haji menyebabkan sebagian calon jamaah haji beralih untuk menunaikan ibadah umroh yang diselenggarakan oleh biro atau travel penyelenggara umroh.

Meningkatnya minat masyarakat untuk melaksanakan ibadah umroh kemudian dimanfaatkan oleh sekelompok orang sebagai ajang bisnis. Sehingga biro atau travel penyelenggara Perjalanan Umroh bermuncullan

${ }^{1}$ Mochamad Saleh dan Shanti Wahyuni, Tata Cara Haji Dan Umrah Yang Benar, Ragam Media, Yogyakarta, 2015, hal. 11 seperti jamur di musim hujan. Dilihat dari aspek bisnis, banyaknya biro perjalanan umroh menyebabkan terjadinya persaingan diantara pelaku usaha biro perjalanan umroh. Biaya lebih murah dengan fasilitas yang lebih istimewa biasanya menjadi bagian promosi yang ditawarkan kepada calon jamaah.

Sayangnya masyarakat sangat mudah tergiur dengan promosi dan iklan yang ditawarkan, sehingga terkadang menghilangkan nalar berpikir yang logika. Berniat untuk berangkat menunaikan ibadah umroh dengan biaya murah, banyak masyarakat akhirnya menjadi korban penipuan dan penggelapan oleh sejumlah travel perjalanan umroh.

Di tahun 2017, masyarakat dikejutkan dengan terungkapnya kasus penipuan dan penggelapan dana umroh oleh biro penyelenggara first travel. Biro perjalanan first travel menawarkan biaya yang begitu murah, yaitu sebesar Rp.14.5jt. Biaya tersebut dan sangat jauh berbeda jika dibandingkan dengan biaya perjalanan ibadah umroh yang ditetapkan oleh biro penyelenggara umroh lainnya, yakni sebesar Rp. 20 juta.

Kasus penipuan dan penggelapan dana umroh oleh first travel bukanlah pertama kalinya terjadi, kasus serupa sebelumnya juga pernah terjadi di kota Medan. Pada tahun 2015, Nabila Khadijah Khairun (tersangka) dilaporkan ke Polda Sumut, karena melarikan uang jamaah sebesar Rp. 7.7 miliar. Nabila merupakan pemilik PT. Nabila Putra Mandiri, modus penipuan yang dilakukan oleh Nabila dengan cara mendatangi sejumlah perusahaan travel 
umroh dan menawarkan tiket murah yang jauh di bawah harga normal. ${ }^{2}$

Kasus penipuan yang belakang ini menjadi topik hangat di kota Medan adalah penipuan jamaah umroh oleh travel Abu Tours. Setidaknya 2700 orang calon jamaah umroh menjadi korban penipuan bos travel Abu Tours. Beberapa kasus penipuan oleh Biro Penyelenggara Perjalanan Umroh, dapat diuraikan sebagai berikut:

Tabel. 1.

\section{Kasus Penipuan dan Penggelapan Dana Umroh}

\begin{tabular}{|c|c|c|c|c|}
\hline $\begin{array}{l}N \\
0\end{array}$ & $\begin{array}{c}\text { Nama } \\
\text { Perusahaan }\end{array}$ & Korban & Kerugian & Keterangan \\
\hline 1 & First Travel & 50.000 & 848 miliar & $\begin{array}{l}\text { Vonis } 20 \text { thn \& } \\
\text { Proses banding }\end{array}$ \\
\hline 2 & Abu Tours & 27.000 & $\begin{array}{l}\text { tidak } \\
\text { diketahui }\end{array}$ & Penyidikan \\
\hline 3 & $\begin{array}{ll}\text { PT. SBL } \\
\text { Bandung }\end{array}$ & 12.845 & 300 miliar & Proses hukum \\
\hline 4 & $\begin{array}{ll}\text { PT. } & \text { UHNT } \\
\text { Solo } & \\
\end{array}$ & 1800 & 38 Miliar & Proses hukum \\
\hline 5 & $\begin{array}{l}\text { PT. Religi } \\
\text { Sukses }\end{array}$ & & $144, \mathrm{jt}$ & $\begin{array}{l}\text { Vonis } 2 \text { Thn PN. } \\
\text { Surabaya }\end{array}$ \\
\hline 6 & PT. Baitullah & & 1,7 miliar & $\begin{array}{l}\text { Vonis } 2 \text { thn } 3 \text { bln } \\
\text { PN. Baturaja }\end{array}$ \\
\hline 7 & $\begin{array}{l}\text { PT. Lintas } \\
\text { Sukses }\end{array}$ & & 40 miliar & Vonis 17 thn \\
\hline 8 & Windarti & - & - & $\begin{array}{l}\text { Vonis } 2 \text { thn PN. } \\
\text { Jakut. }\end{array}$ \\
\hline 9 & $\begin{array}{l}\text { Bambang } \\
\text { Sumitro }\end{array}$ & - & - & 10 bln penjara \\
\hline
\end{tabular}

Dari bebepara kasus penipuan dana jamaah umroh di atas, diketahui bahwa kejahatan penipuan terhadap calon jamaah umroh sebagian besar dilakukan oleh perusahaan (korporasi) Biro Penyelenggaran Perjalanan Umroh. Selain itu, dalam menjerat korbannya perusahaan biasanya menawarkan paket umroh murah kepada para calon jamaah. Namun, permasalahan ini tidaklah terjadi

\footnotetext{
${ }^{2}$ Sumut Pos. 11 Jamah Umroh Laporkan Bos Travel Nafisah. 4 April 2018, diakses melalui: https://sumutpos.co.id, tanggal 25 November 2018. Pukul. 21. 45. Wib.
}

sesederhana yang dibayangkan. Dalam pelaksanaan kegiatan usahanya, perusahaan penyelenggara perjalanan ibadah umroh tentunya terlebih dahulu memperoleh izin dari pemerintah dan sekaligus mendapat pengawasan dari pemerintah.

Berdasarkan uraian di atas, maka dapat dipahami bahwa maraknya penipuan dana umroh oleh perusahaan penyelenggara perjalanan umroh tidak terlepas dari peran pemerintah sebagai pihak yang memberi izin usaha dan sebagai pihak yang bertanggungjawab untuk melakukan pengawasan terhadap pelaksanaan kegiatan usaha yang dilakukan Biro Penyelenggara Perjalanan Ibadah Umroh.

Fenomena maraknya penipuan dan penggelapan dana umroh yang terjadi dimasyarakat, khususnya di kota Medan haruslah menjadi perhatian serius pemerintah. Upaya pencegahan dan penanggulangan harus segera dilakukakan, sehingga tidak lagi muncul korban di tengah masyarakat.

Berdasarkan latar belakang di atas, penulis tertarik meneliti permasalahan lebih lanjut mengenai penipuan dan penggelapan dana umroh dalam perspektif kriminologi, yang bertujuan untuk mengetahui faktor penyebab terjadinya penipuan dan penggelapan dana calon jamaah umroh oleh perusahaan travel umroh, dengan judul tesis: "Analisis Kriminologi Kejahatan Penggelapan dan Penipuan Dana Umroh Oleh Biro Penyelengara Perjalanan Ibadah Umroh PT. Nabila Travel Di Kota Medan". 


\section{B. Permasalahan}

Adapun rumusan permasalahan dalam penelitian ini adalah sebagai berikut:

1. Bagaimana pengaturan tindak pidana penipuan dan penggelapan dalam peraturan perundang-undangan di Indonesia?

2. Apakah faktor penyebab terjadinya penggelapan dan penipuan dana umroh oleh biro penyelenggara perjalanan ibadah umroh PT. Nabila Putra Mandiri?

3. Bagaimana kebijakan pemerintah dalam mencegah dan menanggulangi terjadinya penipuan dan penggelapan dana calon jamaah umroh oleh biro penyelenggara perjalanan umroh?

\section{Metode Penelitian}

Penelitian ini termasuk pada jenis penelitian yuridis normatif dan empiris. Melalui pendekatan yuridis normatif dapat diketahui apakah undang-undang, asas-asas, konsep hukum, dan peraturan perundangan yang berlaku saat ini telah mendukung upaya pencegahan dan penanggulangan kejahatan penipuan dan penggelapan dana umroh oleh Biro Penyelenggara Perjalanan Umroh PT. Nabila Putri Mandiri.

Penelitian hukum normatif bertujuan untuk mengetahui apakah politik kriminal atau kebijakan kriminal yang dilakukan pemerintahan, baik itu melalui perumusan peraturan perundang-undangan, penegakan hukum melalui sarana penal dan upaya-upaya non penal telah mampu untuk mencegah dan menanggulangi terjadinya penipuan dan penggelapan dana umroh oleh Biro Penyelenggara Perjalanan Umroh PT. Nabila Putri Mandiri.
Penelitian yuridis empiris dilakukan di wilayah Kota Medan, guna mengumpulkan data primer, sebagai upaya untuk mengumpulkan data-data yang valid mengenai objek permasalahan. Penelitian empiris dalam penelitian ini dilaksanakan di berbagai instansi pemerintah yang relevan dan berkompetensi dalam memberikan keterangan-keterangan terkait dengan permasalahan penelitian. $\mathrm{Di}$ samping itu, juga dilakukan penelitian di beberapa Biro Penyelenggara Perjalanan Umroh, dan juga masyarakat

Analisis data dalam penelitian ini menggunakan analisis data kualitatif. Analisis data kualitatif adalah upaya yang dilakukan dengan jalan bekerja dengan data, mengorganisasikan data, memilah-milahnya menjadi satuan yang dapat dikelola, mensintesiskannya, mencari dan menemukan pola, menemukan apa yang penting dan apa yang dipelajari dan memutuskan apa yang dapat diceritakan kepada orang lain.

\section{Pembahasan}

A. Pengaturan Tindak Pidana Penipuan Dan Penggelapan Dalam Peraturan Perundang-Undangan Di Indonesia

\section{Tindak Pidana Penipuan dalam KUHP}

Penipuan berasal dari kata tipu, yang berarti perbuatan atau perkataan yang tidak jujur, bohong, atau palsu dengan maksud untuk menyesatkan, mengakali,atau mencari untung. Sedangkan penipuan sendiri berdasarkan Kamus Besar Bahasa Indonesia merupakan proses, cara, atau perbuatan melakukan tipu, atau mengecoh kepada orang lain. ${ }^{3}$

3 S. Ananda, Kamus Besar Bahasa Indonesia, Kartika, Surabaya, 2009, hal 364 
Penipuan Bedrog (Oplichting), title XXV buku II KUHP berjudul "Bedrog" yang berarti penipuan dalam arti luas, sedangkan Pasal pertama dari titel itu, yaitu Pasal 378, mengenai tindak pidana "oplicthing" yang berati penipuuan tetapi dalam arti sempit, sedang pasal-pasal lain dari titel tersebut memuat tindak pidana lain yang bersifat penipuan dalam arti luas. Dalam arti luas, penipuan adalah kebohongan yang dibuat keuntungan pribadi, meskipun ia memiliki arti hukum yang lebih dalam, detil jelasnya bervariasi di berbagai wilayah hukum. Perbuatan memanipulasi keterangan untuk mencari keuntungan melalui media internet dapat "ditafsirkan" sebagai perbuatan menyesatkan yang ada dalam delik penipuan seperti yang tertuang dalam Pasal 378 KUHP dan Pasal 379a KUHP.

Bab XXV Buku II KUHP memuat berbagai bentuk penipuan yang dirumuskan Dalam 20 Pasal. Diantara bentuk-bentuk penipuan itu memilki nama sendiri yang khusus, yang dikenal sebagai penipuan adalah yang dirumuskan didalam Pasal 378 KUHP :

Barangsiapa dengan maksud untuk menguntungkan diri sendiri atau orang lain secara melawan hukum dengan memakai nama palsu atau martabat (hoedanigheid) palsu, dengan tipu muslihat, ataupun rangkaian kebohongan, menggerakkan orang lain untuk menyerahkan barang sesuatu kepadanya, atau supaya memberi hutang maupun menghapus piutang, diancam, karena penipuan, dengan pidana penjara paling lama 4 (empat) tahun.

Rumusan penipuan dalam KUHP bukanlah suatu definisi melainkan hanyalah untuk menetapkan unsur-unsur suatu perbuatan sehingga dapat dikatakan sebagai penipuan dan pelakunya dapat dipidana. Unsur-unsur tindak pidana penipuan dalam Pasal 378 KUHP, diantaranya adalah: ${ }^{4}$

a. Unsur subjektif : "dengan sengaja atau dengan maksud"

1) Menguntungkan diri sendiri atau orang lain.

2) Dengan cara melawan hukum

b. Unsur objektif :

1) Membujuk atau menggerakkan orang lain untuk menyerahkan sesuatu barang; atau

2) Membujuk atau menggerakkan orang lain membuat hutang; atau

3) Membujuk atau menggerakkan orang lain meniadakan hutang.

Membujuk atau menggerakan orang lain itu dilakukan dengan menggunakan $:^{5}$

a. nama palsu atau keadaan palsu;

b. akal cerdik atau tipu muslihat;

c. rangkaian kebohongan.

Penggunaan nama palsu yaitu, penggunaan yang bukan nama sendiri, tetapi nama orang lain, bahkan penggunaan nama yang tidak memiliki oleh siapapun juga termasuk dalam penggunaan nama palsu, dalam anam ini termasuk juga nama tambaham dengan syarat yang tidak dikenal oleh orang lain. Sedangkan keadaan palsu adalah pernyataan dari seseorang, bahwa ia ada dalam suatu keadaan tertentu, keadaan mana memberi hak-hak kepada orang yang ada dalam keadaan itu, misalnya : seseorang swasta mengaku sebagai anggota Polisi, atau sebagai petugas PLN.

4 S. R Sianturi, Tindak Pidana Di KUHP Berikut Uraiannya, Alumni, Jakarta, 2002, hal. 622

${ }^{5}$ R.Soesilo, Kitab Undang-Undang Hukum Pidana (KUHP), serta Komentar-Komentarnya Lengkap Pasal demi Pasal, Bogor; Politiea, Bogor, 2010, hal. 261 
Adapun sarana atau alat dalam melakukan penipuan lainnya adalah dengan menggunakan akal cerdik atau tipu muslihat. Tipu muslihat adalah suatu tipu yang demikian liciknya, sehingga seseorang yang berpikiran normal dapat tertipu. Suatu tipu muslihat sudah cukup, asal cukup liciknya. SR. Sianturi menjelaskan, tipu muslihat adalah suatu tindakan yang dapat disaksikan oleh orang lain baik disertai maupun tidak disertai dengan suatu ucapan, yang dengan tindakan itu si penipu menimbulkan suatu kepercayaan akan sesuatu atau pengharapan bagi orang lain. ${ }^{6}$ Misalnya, surat-surat palsu, memperlihatkan barang yang palsu adalah tipu muslihat.

Rangkaian kebohongan, bahwa dalam perbuatan ini mensyaratkan adanya beberapa kata bohong yang diucapkan, suatu kata bohong saja dianggap tidak cukup sebagai alat penggerak ataupun alat bujuk. Rangkaian katakata bohong yang diucapkan secara tersusun, hingga merupakan suatu cerita yang dapat diterima sebagai sesuatu yang logis dan benar. Jadi kata-kata itu tersusun hingga kata yang satu membenarkan atau memperkuat kata yang lain. Kesemua sarana atau alat pembujuk/penggerak dalam perbuatan penipuan tersebut di atas dapat digunakan secara alternatif maupun secara komulatif.

Unsur kesalahan dalam tindak pidana penipuan sebagaimana diatur dalam Pasal 378 KUHP, dirumuskan "dengan maksud". Hal ini berarti bahwa kesalahan dalam tindak pidana ini berbentuk kesengajaan (dolus). Penggunaan kata "dengan maksud" yang ditempatkan pada awal kalimat berfungsi rangkap, yaitu baik sebagai pengganti dari kesengajaan maupun sebagai pernyataan tujuan. ${ }^{7}$

Sebagai unsur sengaja, maka tentunya si pelaku (penipu) menyadari atau menghendaki suatu keuntungan untuk diri sendiri atau orang lain. Bahkan si pelaku juga menyadari ketidakberhakannya atas suatu keuntungan yang diperolehnya tersebut. Pelaku juga menyadari bahwa sarana yang digunakannya adalah suatu kebohongan yang memperdaya korbannya.

Unsur menguntungkan diri sendiri atau orang lain dalam tindak pidana penipuan merupakan unsur yang bersifat formal. Artinya, dalam fungsinya sebagai tujuan berarti tidak harus selalu menjadi kenyataan keuntungan yang diharapkan itu. Hal yang terpenting adalah bahwa pada waktu melakukan kebohongan tersebut pelaku mengharapkan suatu keuntungan yang akan diperolehnya dari pihak korban.

Ditentukannya delik penipuan adalah untuk melindungi seseorang dari penipuan. Namun yang dilindungi itu tidaklah termasuk seseorang "yang gampangan percaya" kepada "rayuan" si petindak. Dalam hal ini yang diambil ukurannya adalah apakah dari sekian banyak yang mendengar itu atau jika hal itu diutarakan kepada sekian banyak orang, lebih banyak yang percaya atau sebaliknya. Dalam hal lebih banyak yang tidak percaya, maka kepada si pelaku tidak tepat diterapkan pasal ini.

Seperti halnya kebiasaan disuatu daerah, kendati kebiasaaan itu kurang baik, tetapi perlu pula diperhatikan dalam kaitannya dengan 
penerapan pasal ini. Misalnya suatu kebiasaan di daerah tertentu untuk menawarkan barang daganganya kurang dari dua kali lipat dari harga jual yang sebenarnya serta diembeli dengan mempromosikan mutu yang melangit dari dagangan itu, tidaklah dapat dipandang sebagai penipuan.

Buku II KUHP memuat berbagai bentuk penipuan yang dirumuskan dalam 20 Pasal. Delik penipuan dalam KUHP diawali dari Pasal 378 sampai dengan Pasal 392 KUHP. Pasal 379 Tentang Pencurian Ringan, Pasal 380 Ayat (1) Tentang Pemalsuan Nama dan Tanda atas Suatu Karya atau Ciptaan Orang, Pasal 381 dan 382 Tentang Penipuan Terhadap Perasuransian, Pasal 383 bis Tentang Persaingan Curang, Pasal 383 Tentang Penipuan dalam Jual-Beli, Pasal 383 bis Tentang Penipuan dalam Penjualan Beberapa Salinan (copy) cognosement, Pasal 384 Tentang Penipuan dalam Jual-Beli dalam Bentuk Geprivillegeerd, Pasal 385 Tentang Stellionat, Pasal 386 Tentang Penipuan dalam Penjualan Bahan Makanan dan Obat, Pasal 387 Penipuan dalam pemborongan, Pasal 388 Penipuan Terhadap Penyerahan Barang untuk Angkatan Perang, Pasal 389 Tentang Penipuan terhadap Batas Pekarangan, Pasal 390 Tentang Penyiaran Kabar Bohong, Pasal 391 Penipuan dengan Memberikan Gambaran Tidak Benar Tentang Surat Berharga, Pasal 392 Tentang Penipuan Nama, Firma, atau Merek atas Barang Dagangan.

\section{Tindak Pidana Penggelapan dalam KUHP}

Penggelapan dalam Kamus Besar

Bahasa Indonesia diartikan sebagai proses, cara dan perbuatan menggelapkan (penyelewengan) yang menggunakan barang secara tidak sah. Dapat diuraikan selanjutnya bahwa penggelapan dapat dikatakan sebagai perbuatan merusak kepercayaan orang lain dengan mengingkari janji tanpa perilaku yang baik.

Lamintang dan Djisman Samosir mengatakan akan lebih tepat jika istilah penggelapan diartikan sebagai "penyalahgunaan hak" atau "penyalahgunaan kepercayaan". Lebih lanjut, Van Haeringen yang dikutip Lamintang dan Djisman Samosir memberi arti pada istilah "verduistering" atau "penggelapan" itu sebagai "geheel donker maken" ataupun sebagai "uitstralinc van licht beletten" yang artinya "membuat segalanya menjadi gelap" atau "menghalangi memancarnya sinar". ${ }^{8}$

Lamintang dalam E.Y Kanter dan SR. Sianturi berpendapat bahwa arti penggelapan yang pada dasarnya sama dengan uraian Pasal 372 KUHP. Namun, pada penggelapan adalah penyalahgunaan hak oleh seorang, yang kepercayaan tersebut diperolehnya tanpa adanya unsur melawan hukum. Penyebutan penyalahgunaan hak akan memberikan kemudahan untuk mengetahui perbuatan apa sebenarnya yang dilarang dan diancam pidana dalam ketentuan tersebut. ${ }^{9}$

Berbeda dengan pendapat yang dikemukakan Lamintang, R. Soesilo memaknai

8 Lamintang dan Djisman Samosir, Delik-Delik Khusus (Kejahatan yang Ditujukan Terhadap Hak Milik dan Lain-Lain Hak yang Timbul dari Hak Milik), Tarsito, Bandung, 1989, hal. 17

${ }^{9}$ EY Kanter dan SR. Sianturi, Asas-asas Hukum Pidana Di Indonesia dan Penerapannya, Storia Grafika, Jakarta, 2002, hal. 95. 
"penggelapan" sebagai kejahatan yang hampir sama dengan pencurian dalam Pasal 362 KUHP. Bedanya ialah bahwa pada pencurian barang yang dimiliki itu masih berada ditangan pencuri dan masih harus diambil oleh pelaku, sedang pada penggelapan waktu dimilikinya barang itu sudah ada ditangan si pembuat dan tidak diperoleh dengan jalan kejahatan atau melawan hukum. ${ }^{10}$

Mengenai tindak pidana penggelapan diatur dalam Bab XXIV Pasal 372 KUHP sampai Pasal 377 KUHP, dengan demikian maka tindak pidana penggelapan adalah suatu perbuatan yang bertentangan dengan ketentuan Pasal 372 s/d 377 KUHP. Tindak pidana penggelapan dalam bentuk pokoknya disebutkan sebagai berikut:

Barang siapa dengan sengaja dan dengan melawan hukum memiliki barang yang sama sekali atau sebagian kepunyaan orang lain dan berada dalam kekuasaannya bukan karena kejahatan, dipidana karena penggelapan, dengan pidana selama-lamanya empat tahun atau denda sebesar-besarnya sembilan ratus rupiah.

Unsur kesalahan dalam tindak pidana penggelapan adalah kesengajaan (dolus). Hal ini dapat dilihat secara tegas pada penempatan kata "dengan sengaja" pada awal rumusan delik dalam pasal tersebut. Dengan demikian, pelaku menyadari bahwa dirinya secara melawan hukum memiliki sesuatu barang. Menyadari bahwa barang itu adalah dalam kekuasaannya bukan karena kejahatan. Kejahatan penggelapan dipandang telah sempurna jika tindakan pemilikan itu sudah terjadi.

${ }^{10}$ R.Soesilo, Op.Cit. hal. 258.
Penggelapan dalam KUHP, dapat dibedakan beberapa bentuk/jenis, yaitu: ${ }^{11}$

a. Penggelapan dalam bentuk pokok (Pasal 372).

b. Penggelapan dalam bentuk-bentuk yang diperberat (Pasal 374-375).

c. Penggelapan ringan (Pasal 373).

d. Penggelapan dalam kalangan keluarga (Pasal 376).

Dimaksud penggelapan dalam bentuk pokok atau penggelapan biasa yaitu delik penggelapan yang diatur dalam Pasal 372 KUHP, yang di dalamnya mengandung unsurunsur pokok tindak pidana penggelapan, yang meliputi: ${ }^{12}$

a. Unsur-unsur objektif yang terdiri dari:

1) Perbuatan memiliki

2) Sesuatu barang

3) Seluruhnya atau sebagian adalah milik orang lain

4) Yang berada dalam kekuasaannya bukan karena kejahatan

5) Secara melawan hukum.

b. Unsur- unsur subjektif yaitu dengan sengaja.

Unsur-unsur pokok dari tindak pidana penggelapan sebagaimana diatur dalam Pasal 372 KUHP adalah :

a. Unsur-unsur Objektif

1) Perbuatan memiliki

2) Sesuatu barang

3) Sebagian atau seluruhnya milik orang lain

4) Berada dalam kekuasaannya bukan karena kejahatan

11 Adami Chazawi, Kejahatan Terhadap Harta Benda, Bayumedia, Malang, 2003, hal. 69. ${ }_{12}$ S.R. Sianturi, Op.Cit., hal. 146. 
b. Unsur-unsur subjektif

Unsur subjektif dalam tindak pidana penggelapan yang diatur dalam Pasal 372 KUHP, terdiri dari 2 (dua) unsur, yaitu unsur sengaja dan melawan hukum. Kesengajaan, menurut Moeljatno dalam Zainal Abidin Farid, bahwa yang dimaksud dengan kesengajaan adalah pengetahuan, yaitu adanya hubungan antara pikiran atau intelek pelaku dengan perbuatan yang dilakukan, maka sesungguhnya kesengajaan hanya terdiri atas dua corak, yaitu sengaja sebagai kepastian dan sengaja sebagai kemungkinan. ${ }^{13}$ Sedangkan unsur melawan hukum, berarti perbuatan seseorang melanggar atau bertentangan dengan kaidah materiil. ${ }^{14}$

\section{B. Faktor Penyebab Terjadinya Penggelapan Dan Penipuan Dana Umroh Oleh Biro Penyelenggara Perjalanan Ibadah Umroh PT. Nabila Putra Mandiri}

Penipuan dan penggelapan dana umroh yang dilakukan oleh penyelenggara perjalanan haji dan umroh adalah suatu kejahatan penggelapan dan penipuan yang hanya dapat dilakukan oleh orang-orang tertentu, yakni mereka yang membuka kegiatan usaha biro perjalanan umroh dan haji yang memperoleh izin dari Kementerian Agama Negara Republik Indonesia.

$$
\text { Mengenai penipuan dan }
$$
penggelapan dana umroh yang dilakukan oleh PT. Nabila Putra Mandiri, dapat dikatakan bahwa modus operandi yang dilakukan oleh tersangka dalam melakukan

13 Zainal Abidin Farid, Hukum Pidana I, Sinar Grafika, Jakarta, 2001, hal. 295.

${ }_{14}$ Ibid., hal. 241. aksi kejahatannya cukup rapi dan matang. Tersangka dalam hal ini memanfaatkan banyak biro penyelenggara perjalanan haji dan umroh untuk dijadikan sebagai target atau korban kejahatannya.

Terkait dugaan penipuan dan penggelapan yang dilakukan oleh Nabilah Khadijah, diketahui bahwa modus penipuan yang dilakukan tersangka adalah:

Penawaran tiket umroh promo kepada korban seharga satu tiket Rp9 jutaan, sementara normalnya biaya umroh ketika itu sekitar Rp14 jutaan. Untuk meyakinkan korban, tersangka menyarankan agar korban datang terlebih dahulu ke kantor tersangka dan melihat-lihat kantor travelnya di daerah Jalan Marindal. Akhirnya, korban pun percaya dan mencoba membeli 15 tiket pesawat untuk keberangkatan jamaah umrohnya pada bulan Ramadan tahun 2014. Ternyata, jamaahnya pun berangkat ke Makkah sesuai yang dijanjikan. Setelah itu, pada bulan Oktober 2014, tersangka kembali menawarkan paket umroh kepada dengan harga yang tak jauh berbeda di bawah normal untuk keberangkatan Januari, Februari, dan Maret 2015. Total tiketnya sebanyak 750 kursi. Jadi, modus awalnya tersangka mengorbankan uangnya terlebih dahulu untuk menutupi selisih harga 15 tiket pesawat yang di bawah harga normal. Setelah targetnya percaya, tersangka menawarkan kembali paket umroh murah dengan jumlah yang lebih banyak. Pada penawaran ini tersangka menyatakan bahwa terdapat batasan waktu harga promo, sehingga targetnya mau tidak mau percaya dan membeli promo yang ditawarkan oleh tersangka. ${ }^{15}$

15 Keterangan pelapor pada pembuatan laporan di Direktorat Reskrimum Poldasu dengan Nomor LP/031///2015/ SPKT III tertanggal 10 Januari 2015. 
Modus penipuan dana umroh adalah suatu bentuk kejahatan di bidang bisnis yang dilakukan oleh perusahaan biro penyelenggara perjalanan haji dan umroh umumnya menggunakan skema bisnis ponzi. Skema bisnis ponzi adalah suatu skema bisnis yang dicetuskan oleh Charles Ponzi yang menjadi terkenal pada tahun 1920. Skema Ponzi didasarkan dari praktik arbitrasi dari kupon balasan surat internasional yang memiliki tarif berbeda di masing-masing negara.

Keuntungan dari praktik ini kemudian dipakai untuk membayar kebutuhannya sendiri dan investor sebelumnya. Ponzi menyatakan bahwa uang yang diperoleh dari investasinya akan dikirimkan ke agen di luar negeri, seperti Italia, di mana mereka membeli kupon tersebut.

Berdasarkan modus operandi terjadinya tindak pidana penipuan dana umroh oleh sejumlah biro perjalanan haji dan umroh, dapat diketahui bahwa penyebab terjadinya penipuan dana jamaah umroh antara lain adalah:

1. Meningkatnya Jumlah Jamaah Umroh di Indonesia

2. Umroh menjadi gaya hidup (life style)

3. Karakter atau budaya masyarakat

4. Sistem Penyelenggara Haji Dan Umroh (PHU) dan Lemahnya Pengawasan Kementerian Agama Republik Indonesia.

C. Kebijakan Pemerintah Dalam Mencegah dan Menanggulangi Terjadinya Penipuan dan Penggelapan Dana Calon Jamaah

\section{Umroh Oleh Biro Penyelenggara Perjalanan Umroh}

Berkenaan dengan penyelenggaraan perjalanan ibadah umroh, pemerintah telah menerbitkan beberapa peraturan perundangundangan yang menjadi dasar hukum bagi penyelenggaraan perjalanan ibadah umroh, diantaranya :

1. Undang-Undang Nomor 13 Tahun 2008 tentang Penyelenggaraan Haji serta perubahannya melalui Undang-undang Nomor 34 Tahun 2009 Tentang Perubahan Atas Undang-Undang Nomor 13 Tahun 2008 tentang Penyelenggaraan Haji.

2. Peraturan Pemerintah Nomor 79 Tahun 2012 Tentang Usaha Perasuransian dan Peraturan Menteri Agama (Permenag) Nomor 8 Tahun 2018 tentang Penyelenggaraan Perjalanan Ibadah Umroh.

Kebijakan Pemerintah mengatasi permasalahan haji dan umroh adalah dengan membuat Sistem Informasi Pengawasan Terpadu Umroh dan Haji Khusus (SIPATUH) dikembangkan dalam rangka memperkuat fungsi pengawasan penyelenggaraan perjalanan ibadah umroh di Indonesia dan perluasan cakupan pengawasan sejak pendaftaran sampai kepulangan. Sistem ini memuat sejumlah informasi, di antaranya:

a. Pendaftaran jemaah umroh;

b. Paket perjalanan yang ditawarkan PPIU;

c. Harga paket;

d. Pemantauan penyediaan tiket yang terintegrasi dengan maskapai penerbangan, dan 
e. Pemantauan akomodasi yang terintegrasi dengan sistem muassasah (badan atau yayasan yang didirikan sebagai pengganti syekh jemaah Haji di Makkah) di Arab Saudi.

Sistem Informasi Pengawasan Terpadu Umroh dan Haji Khusus, menurut peraturan ini juga memuat alur pemesanan visa yang terintegrasi dengan Kedutaan Besar Saudi Arabia, validasi identitas jemaah yang terintegrasi dengan Duk-capil dan pemantauan keberangkatan dan kepulangan yang terintegrasi dengan Imigrasi. Melalui Sistem Informasi Pengawasan Terpadu Umroh dan Haji Khusus, maka jemaah akan memperoleh nomor registrasi pendaftaran sebagai bukti proses pendaftaran yang dilakukan sesuai peraturan. Artinya, proses akhir pendaftaran adalah keluarnya nomor registrasi umroh (sejenis nomor porsi dalam pendaftaran ibadah haji). Dengan nomor registrasi ini, jemaah dapat memantau proses persiapan keberangkatan yang dilakukan oleh PPIU, mulai dari pengadaan tiket, pemesanan akomodasi, hingga penerbitan visa. Melalui sistem ini jemaah dapat memonitor seluruh proses pengurusan perjalanan ibadah umroh sejak pendaftaran hingga kembali ke Tanah Air.

Adapun langkah-langkah dalam menanggulangi tindak pidana penipuan dana umroh oleh Biro PPIU, antara lain:

1. Penyuluhan pada masyarakat

2. Penentuan standar biaya perjalanan umroh oleh biro PPIU

3. Pengawasan terhadap Biro PPIU

\section{Penutup}

A. Kesimpulan

1. Memperhatikan pengaturan pidana penjara dan pelatihan kerja sebagai sanksi pidana terhadap anak yang melakukan tindak pidana terdapat pada Pasal 71 sampai dengan Pasal 78 UU SPPA. Penjatuhan sanksi terhadap anak Pengaturan penipuan dan penggelapan dana calon jamaah umroh dalam perundang-undangan di Indonesia, paling tidak terdapat tiga undang-undang yang relevan, yaitu Undang-Undang No. 1 Tahun 1956 tentang KUHP, UndangUndang No. 8 tahun 1999 Tentang Perlindungan Konsumen dan UndangUndang No. 13 Tahun 2008 Tentang Penyelenggaraan Ibadah haji dan Umroh.

2. Faktor penyebab terjadinya penggelapan dan penipuan dana umroh oleh biro penyelenggara perjalanan ibadah umroh oleh PT. Nabila Putra Mandiri, dibedakan dalam dua bentuk, yaitu internal pelaku dan eksternal pelaku. Faktor internal pelaku, yaitu adanya dorongan dalam diri tersangka untuk memenuhi hasrat (hawa nafsu) yang tidak terbatas dan ketidak mampuan tersangka meraih mimpinya dalam mencapai kesuksesan dan kekayaan dengan tetap mematuhi aturan hukum atau secara sah (legitimated means). Sedangkan faktor eksternal pelaku didorong oleh beberapa faktor, yaitu : meningkatnya Jumlah Jamaah Umroh di Indonesia sehingga dimanfaatkan menjadi peluang bisni. Umroh menjadi gaya hidup (life style), sehingga komunitas umroh tidak lagi berasal dari kalangan atas, tetapi masyarkat menengah ke bawah. Karakter atau budaya 
masyarakat yang mudah percaya dan tergiur dengan iming-iming yang menguntungkan. Sistem Penyelenggara Haji Dan Umroh (PHU) yang belum baik dan Lemahnya Pengawasan Kementerian Agama Republik Indonesia.

3. Kebijakan pemerintah dalam mencegah dan menanggulangi terjadinya penipuan dan penggelapan dana calon jamaah umroh oleh biro penyelenggara perjalanan umroh, yaitu dengan membuat kebijakan baru dalam sistem penyelenggaraan haji dan umroh melalui Sistem Informasi Pengawasan Terpadu Umroh dan Haji Khusus yang dibangun berbasis elektronik. Melakukan kebijakan baru ini maka terjadi perluasan cakupan pengawasan, yakni mulai sejak pendaftaran sampai kepulangan, yang meliputi : a. Pendaftaran jemaah umroh; b. Paket perjalanan yang ditawarkan PPIU; c. Harga paket; d. Pemantauan penyediaan tiket yang terintegrasi dengan maskapai penerbangan, dan Pemantauan akomodasi yang terintegrasi dengan sistem muassasah (badan atau yayasan yang didirikan sebagai pengganti syekh jemaah Haji di Makkah) di Arab Saudi.

\section{B. Saran}

1. Perlu adanya pembatasan Biro Penyelenggara Perjalanan Umroh oleh Kementerian Agama dan persyaratan yang lebih ketat. Hal ini untuk memudahkan pengawasan oleh Kementerian Agama terhadap Biro PPIU, baik itu yang terdaftar maupun yang tidak terdaftar (illega).
2. Perlu memberikan informasi kepada masyarakat mengenai standart biaya perjalanan ibadah umroh yang resmi ditetapkan oleh Kementerian Agama, sehingga masyarakat tidak mudah tergiur dengan promo-promo paket umroh murah.

3. Perlu penerapan sanksi yang tegas terhadap pelaku tindak pidana penipuan dana umroh, sehingga menimbulkan efek jera bagi pelaku. Dalam hal ini vonis majelis hakim terhadap bos travel umroh first travel sangat patut diapresiasi.

\section{DAFTAR PUSTAKA}

\section{A. Buku}

Adami Chazawi, Kejahatan Terhadap Harta Benda, Bayumedia, Malang, 2003.

EY Kanter dan SR. Sianturi, Asas-asas Hukum Pidana Di Indonesia dan Penerapannya, Storia Grafika, Jakarta, 2002.

Lamintang dan Djisman Samosir, Delik-Delik Khusus (Kejahatan yang Ditujukan Terhadap Hak Milik dan Lain-Lain Hak yang Timbul dari Hak Milik), Tarsito, Bandung, 1989.

Mochamad Saleh dan Shanti Wahyuni, Tata Cara Haji Dan Umrah Yang Benar, Ragam Media, Yogyakarta, 2015.

R.Soesilo, Kitab Undang-Undang Hukum Pidana (KUHP), serta KomentarKomentarnya Lengkap Pasal demi Pasal, Bogor; Politiea, Bogor, 2010.

S. Ananda, Kamus Besar Bahasa Indonesia, Kartika, Surabaya, 2009.

S. R Sianturi, Tindak Pidana Di KUHP Berikut Uraiannya, Alumni, Jakarta, 2002.

Sumut Pos. 11 Jamah Umroh Laporkan Bos Travel Nafisah. 4 April 2018, diakses 
melalui: https://sumutpos.co.id, tanggal 25 November 2018. Pukul. 21. 45. Wib.

Zainal Abidin Farid, Hukum Pidana I, Sinar Grafika, Jakarta, 2001.

\section{B. Undang-Undang}

Undang-Undang No. 1 Tahun 1946 Tentang KUHP.

Undang-Undang Nomor 13 Tahun 2008 Tentang Penyelenggaran Haji.

Peraturan Pemerintah Nomor 17 Tahun 2012 Tentang Pelaksanaan Undang-Undang Nomor 13 Tahun 2008 Tentang Penyelenggaran Ibadah Haji.

Peraturan Menteri Agama Nomor 18 Tahun 2015 Tentang Penyelenggaraan Ibadah Umroh.

Peraturan Menteri Agama Nomor 8 Tahun 2018 Tentang Perubahan. Peraturan Menteri Agama Nomor 18 Tahun 2015 Tentang Penyelenggaraan Ibadah.

\section{Sumber Internet}

Sumut Pos. 11 Jamah Umroh Laporkan Bos Travel Nafisah. 4 April 2018, diakses melalui: https://sumutpos.co.id, tanggal 25 November 2018. Pukul. 21. 45. Wib. 